\title{
Dietary supplementation with safflower seeds differing in fatty acid composition differentially influences serum concentrations of prostaglandin $\mathbf{F}$ metabolite in postpartum beef cows
}

\author{
Mark H.J. GRANT ${ }^{\mathrm{a}}$, Brenda M. ALEXANDER ${ }^{\mathrm{a}}$, Bret W. HESS ${ }^{\mathrm{a}}$, \\ Jeff D. BOTTGER ${ }^{a}$, Doug L. HIXON ${ }^{\mathrm{a}}$, Edward A. VAN KIRK ${ }^{\mathrm{a}}$, \\ Terry M. NETT ${ }^{b}$, Gary E. Moss ${ }^{\mathrm{a}}$ \\ ${ }^{a}$ University of Wyoming Department of Animal Science, Laramie 82071, USA \\ ${ }^{\mathrm{b}}$ Colorado State University, Fort Collins 80523, USA
}

(Received 14 January 2005; accepted 26 May 2005)

\begin{abstract}
Synthesis and secretion of prostaglandin $\mathrm{F}_{2 \alpha}\left(\mathrm{PGF}_{2 \alpha}\right)$ is elevated following parturition and exerts divergent effects on the re-establishment of fertile estrous cycles in cows. The objective of these experiments was to determine if oil seed supplements differing in fatty acid composition differentially influence serum concentrations of the specific PGF $_{2 \alpha}$ metabolite, PGFM. Safflower seed supplements were formulated to provide $5 \%$ of dry-matter intake as fat. In Trial 1, 24 multiparous beef cows were individually fed control (beet pulp-soybean meal) or cracked high-linoleate safflower seed (78\% 18:2n-6) supplements for $80 \mathrm{~d}$ postpartum. Linoleate supplemented cows had greater $(P<$ $0.001)$ serum concentrations of PGFM than control cows. In Trial 2, primiparous beef cows $(n=36)$ were individually fed control (cracked corn-soybean meal), cracked high-linoleate (76\% 18:2n-6) or -oleate ( $72 \% 18: 1 \mathrm{n}-9)$ safflower seed supplements for $92 \mathrm{~d}$ postpartum. As in Trial 1, serum concentrations of PGFM were greater $(P \leq 0.04)$ in linoleate than control or oleate supplemented cows. Serum concentrations of PGFM, however, did not differ $(P=0.40)$ among oleate and control supplemented cows. Although potential impacts on reproductive performance remain to be proven, dietary oil supplements high in linoleate, but not oleate, increased serum concentrations of PGFM compared to control supplements.
\end{abstract}

beef cows / lipid supplementation / prostaglandin

\section{INTRODUCTION}

Feeding oil supplements to cattle is an approach used to enhance the amount of energy contained in diets. In addition to helping meet energy demands, supplemental lipids influence reproductive performance in bovine females. Supplementing cows with dietary lipid increased concentrations of serum lipids $[1,2]$, altered ovarian follicular development [2, 3], and prostaglandin (PG) synthesis [4-6]. In late-pregnant ewes, diets high in linoleic acid increased plasma concentrations of arachidonic acid [7] and production of PG from endometrial tissue $[7,8]$.

* Corresponding author: gm@uwyo.edu 
Specific fatty acid content of lipid supplements affects ruminal biohydrogenation and duodenal flow of fatty acids [9]. Thus, the apparent availability of fatty acids for metabolism is affected by the source of the dietary fat. Linoleic acid that escapes ruminal degradation and is subsequently absorbed from the digestive tract can be desaturated and elongated to form arachidonic acid, a direct precursor of $\mathrm{PGF}_{2 \alpha}$ [10]. The objectives of these experiments were to determine if supplemental safflower-seeds high in linoleic acid affect serum concentrations of the $\mathrm{PGF}_{2 \alpha}$ metabolite, PGFM, and if safflower seed supplements differing in fatty acid content differentially influence serum concentrations of PGFM in beef cows. It was hypothesized that the fatty acid content of oil seed supplementation during the postpartum period may differentially affect prostaglandin synthesis.

\section{MATERIALS AND METHODS}

Animal care and treatments were approved by the University of Wyoming Animal Care and Use Committee.

\subsection{Trial 1: animals}

Twenty-four spring-calving multiparous Angus $\times$ Gelbvieh rotationally-crossed beef cows $(473.9 \pm 9.2 \mathrm{~kg})$ were blocked by weight and body condition score $(4.5 ; 1=$ emaciated, 9 = obese) [11] and randomly allocated to one of two dietary treatments within $24 \mathrm{~h}$ of parturition. The cows were maintained in pens $(6 \mathrm{~m} \times 20 \mathrm{~m})$ and provided rations in individual feeding stations twice daily, at 0700 and 1600 , for 80 d postpartum. The diets were formulated to provide equal amounts of protein and energy using nutrient requirements for 36-mo, $499 \mathrm{~kg}$ lactating cows producing $9.1 \mathrm{~kg}$ of milk per d during peak lactation [12]. Supplements consisted of liquid molasses with the addition of beet pulp-soybean meal (control) or cracked high-linoleate safflower seeds $(77.7 \%$ 18:2n-6, Tab. I; $n=12$
Table I. Fatty acid content (\% total fatty acidsas fed) of supplemental L-Trial 1 (Linoleic, Trial 1) C (Control, Trial 2), L (Linoleic, Trial 2), O (Oleic, Trial 2), diets ${ }^{\mathrm{a}}$.

\begin{tabular}{lcccc}
\hline & \multicolumn{4}{c}{ Supplemental Diet } \\
\cline { 2 - 5 } Fatty Acid & L-Trial 1 & $\mathrm{C}$ & $\mathrm{L}$ & $\mathrm{O}$ \\
\hline $16: 0$ & 6.7 & 13.0 & 6.4 & 5.2 \\
$18: 0$ & 2.1 & 2.6 & 2.6 & 1.7 \\
$18: 1 \mathrm{n}-9$ & 6.3 & 25.9 & 11.2 & 72.2 \\
$18: 2 \mathrm{n}-6$ & 77.7 & 48.5 & 75.7 & 18.5 \\
$18: 3$ & 0.3 & 2.4 & 0.2 & 0.2 \\
Others & 6.9 & 7.6 & 3.9 & 2.2 \\
\hline
\end{tabular}

${ }^{a}$ Control diet for Trial 1 consisted of Beet Pulp with $<1 \%$ ether extract and therefore not a significant source of fatty acids.

per group). The quantity of feedstuffs provided was based on initial cow body weight, calculated as the average of weights obtained on the first and second days of the experiment. Nutrient analysis of the supplements and hay is reported in Table II. In order to provide an equal quantity of energy, control and linoleate supplemented cows were fed the supplement at $0.5 \%$ and $0.3 \%$ of their body weight, respectively. Both groups were fed chopped (Haybuster, Model 2620, Duratech Industries, Jamestown, ND) native grass hay at $2.1 \%$ of their body weight. The supplement was fed first with hay provided after the supplement was completely consumed. Cows remained in their stations for approximately $2 \mathrm{~h}$, or until consumption ceased. All animals had ad libitum access to trace mineralized salt and water.

\subsection{Trial 2: animals}

Thirty-six spring-calving primiparous Angus $\times$ Gelbvieh rotationally-crossed beef cows $(487.9 \pm 10.5 \mathrm{~kg} ; 5.5$ body condition score) [11] were blocked by d of parturition and randomly assigned to one of three dietary supplement treatments beginning $3 \mathrm{~d}$ postpartum. Primiparous cows were assigned to 1 of 6 pens $(6 \mathrm{~m} \times 20 \mathrm{~m})$ equipped with individual feeding stations, large round bale 
Table II. Nutrient analysis (\% DM) of control $(\mathrm{C})^{\mathrm{a}}$, linoleate $(\mathrm{L})$, and oleate $(\mathrm{O})$ supplements and hay fed during Trial 1 and Trial 2.

\begin{tabular}{|c|c|c|c|c|c|c|c|}
\hline \multirow[b]{2}{*}{$\% \mathrm{DM}$} & \multicolumn{4}{|c|}{ Trial 1} & \multicolumn{3}{|c|}{ Trial 2} \\
\hline & $\mathrm{C}$ & $\mathrm{L}$ & $\mathrm{O}$ & Hay & $\mathrm{C}$ & $\mathrm{L}$ & Hay \\
\hline $\mathrm{ADF}$ & 9.76 & 31.20 & 34.73 & 47.17 & 24.73 & 27.14 & 37.89 \\
\hline NDF & 22.39 & 42.82 & 45.06 & 75.71 & 38.55 & 42.68 & 60.69 \\
\hline $\mathrm{CP}$ & 18.51 & 20.14 & 17.78 & 7.75 & 12.63 & 16.55 & 9.70 \\
\hline $\mathrm{Fat}^{\mathrm{b}}$ & 3.80 & 31.36 & 29.32 & 1.11 & 0.55 & 27.14 & 1.38 \\
\hline IVOMD $^{\mathrm{c}}$ & 91.53 & 48.12 & 40.22 & 42.20 & 74.71 & 56.42 & 57.21 \\
\hline
\end{tabular}

${ }^{a}$ Control supplement was corn-soybean (Trial 1) and soybean-beet pulp (Trial 2).

${ }^{\mathrm{b}}$ Fat content of supplement is reported as Total Fatty Acids (Trial 1) and Ether Extract (Trial 2).

${ }^{c}$ IVOMD $=$ in vitro organic matter digestibility. Fatty acids are largely undigested by ruminal microbes but highly digested postruminally; therefore, diets were formulated to have equal total quantities of TDN (NRC, 1982).

self-feeders, and heated watering troughs. Supplements were fed once daily from d 3 through d 92 postpartum. At 0630, the dams were separated from their calves and locked into feeding stations. The supplements consisted of dried molasses with the addition of cracked corn and soybean meal (control), cracked high-linoleate (76\% 18:2n-6, Tab. I), or cracked high-oleate (72\% 18:1n-9, Tab. I) safflower seeds ( $n=12$ per group). Safflower seed supplements were formulated to provide $5 \%$ of dry matter intake as fat. Estimates for hay intake and cow performance were based on Alderton et al. [13]. By using estimated hay intake, the supplements were formulated to contain equal amounts of protein and energy and meet NRC [12] nutritional requirements for a 24-mo, $499 \mathrm{~kg}$ lactating cow (565 kg mature $\mathrm{BW}$ ) producing $9.1 \mathrm{~kg} \mathrm{milk} \cdot \mathrm{d}^{-1}$ during peak lactation. Tabular values for TDN were utilized to formulate supplements [14]. Nutrient analysis of supplements and hay are reported in Table II. To ensure an equal quantity of energy, the amounts of supplement fed were $1.46 \mathrm{~kg}$ to control, $1.62 \mathrm{~kg}$ to linoleate, and $1.43 \mathrm{~kg}$ to oleate supplemented cows. All animals had ad libitum access to hay, trace mineralized salt, and water. Forage intake did not differ among supplemental treatments [15].

\subsection{Collections}

Twice weekly blood samples for the analysis of serum concentrations of PGFM were collected via venipuncture of the coccygeal vein into vacuum tubes (Becton Dickinson Company, Franklin Lakes, NJ) beginning at $\mathrm{d} 25$ through the completion of each feeding trial. Blood was allowed to clot overnight at $4{ }^{\circ} \mathrm{C}$. Serum was separated by centrifugation $(700 \times g)$, and stored at $-20{ }^{\circ} \mathrm{C}$ until analysis.

Additional blood samples were collected over a 4-d period starting at d 30, d 60, and d 90 postpartum for determination of plasma fatty acids in Trial 2. In order to partially account for diurnal variation, blood samples were collected four times during the AM and PM hours at each collection period. Collection frequencies in relation to feeding were $0,3,6,9,12,15,18$, and $21 \mathrm{~h}$ with 0 representing immediately prior to supplementation. All blood samples were collected from the coccygeal vein via venipuncture using $10 \mathrm{~mL}$ EDTA coated Vacutainer (Becton Dikinson Company, Franklin Lakes, NJ) tubes. Blood was centrifuged at $4{ }^{\circ} \mathrm{C}$ at $700 \times g$ within 30 min of collection. Plasma was pooled by sampling period, immediately frozen at $-20{ }^{\circ} \mathrm{C}$, freeze dried, and stored in plastic vials under nitrogen gas at $-80{ }^{\circ} \mathrm{C}$ until analysis. Total lipids were 
extracted from duplicate $500 \mathrm{mg}$ samples of freeze-dried blood plasma. Fatty acid methyl esters were prepared using $14 \% \mathrm{BF}_{3}$ in methanol to insure methyl esterification of esterified and non-esterified fatty acids [16].

\subsection{Laboratory analysis}

Serum concentrations of PGFM were quantified in extracts of serum by RIA [17] and infer concentrations of $\mathrm{PGF}_{2 \alpha}$ [18]. In brief, $2 \mathrm{~mL}$ aliquots of serum were acidified with $150 \mu \mathrm{L}$ of $1.0 \mathrm{M}$ formic acid and extracted twice with $5 \mathrm{~mL}$ of ethyl acetate. The combined extracts were dried under $\mathrm{N}_{2}$ and reconstituted in $1 \mathrm{~mL}$ of gel-PBS. When necessary, the samples were further diluted with gel-PBS before they were assayed. Recovery of $\left[{ }^{3} \mathrm{H}\right]$-PGFM was $94.5 \%$ [17]. Antigen (PGFM-tyrosine methyl ester) was labeled with $\mathrm{I}^{125}$ using chloramine $\mathrm{T}$ and separated on Sephadex G-25. Rabbit antiPGFM at a working dilution of 1:24000 was utilized with a cross-reactivity of $\sim 1 \%$ to $\mathrm{PGE}_{2}$. No other significant cross-reactivity of PG are noted with this antibody [17]. Samples from Trial 1 were analyzed in a single assay with an intra-assay $\mathrm{CV}$ of $8.0 \%$. Samples from Trial 2 were analyzed in three assays with intra- and inter-assay CV of $10.8 \%$ and $16.5 \%$, respectively.

Isolated plasma fatty acid methyl esters (Trial 2) were separated using a HewlettPackard 5890 GLC (Hewlett-Packard, Avondale, PA) equipped with a flame ionization detector and a $100 \mathrm{~m} \times 0.25 \mathrm{~mm}$ (i.d.) fused silica capillary column (SP-2560, $0.2 \mu \mathrm{m}$ film thickness, Supelco, Bellefonte, PA). Oven temperature was maintained at $175^{\circ} \mathrm{C}$ for $40 \mathrm{~min}$, and then increased to $240{ }^{\circ} \mathrm{C}$ at $10{ }^{\circ} \mathrm{C}$ per min. Injector and detector temperatures were $275^{\circ} \mathrm{C}$. Helium was the carrier gas with a split ratio of 50:1 and $0.8 \mathrm{~mL} \cdot \mathrm{min}^{-1}$ column flow. Fatty acid peaks were recorded and integrated using a Hewlett-Packard 3396 integrator. Fatty acids were identified by comparing retention times of peaks with fatty acid methyl ester standard (Nu-Chek Prep, Inc., Elysian, MN and Matreya, Inc., Pleasant Gap, PA).

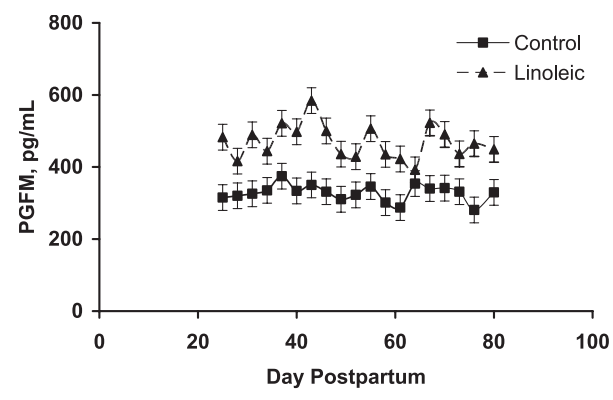

Figure 1. Serum concentrations of $\mathrm{PGF}_{2 \alpha}$ metabolite (PGFM) in multiparous beef cows fed control and linoleate supplements from parturition through d 80 postpartum (least squares means, $\mathrm{SE} \leq 44.1)$. Concentrations were greater $(P<0.001)$ in linoleate than control supplemented cows. Significant day $(P=0.12)$ and treatment by day $(P=0.83)$ interactions were not detected.

\subsection{Statistical analysis}

Concentrations of PGFM and relative weight percentages of fatty acids were analyzed as a split-plot using GLM procedures of SAS (Ver. 8.0, SAS Inst. Inc., Cary, NC) with treatment as the main effect, and day and treatment by day interactions tested as sub-plot effects. Animal within treatment was the error term for treatment effects. Differences among means were separated using Fisher protected LSD [19]. Type III sums of squares were used, and least squares means and associated standard errors are reported.

\section{RESULTS}

Serum concentrations of PGFM in the multiparous cows used in Trial 1 were greater $(P<0.001)$ in cows consuming highlinoleate safflower seed supplement (469 \pm $\left.24 \mathrm{pg} \cdot \mathrm{mL}^{-1}\right)$ than in cows consuming control supplement $\left(328 \pm 23 \mathrm{pg} \cdot \mathrm{mL}^{-1}\right.$, Fig. 1$)$. Significant day $(P=0.12)$ or treatment by day effects $(P=0.83)$ were not detected.

In contrast, serum concentrations of PGFM in the primiparous cows used in 


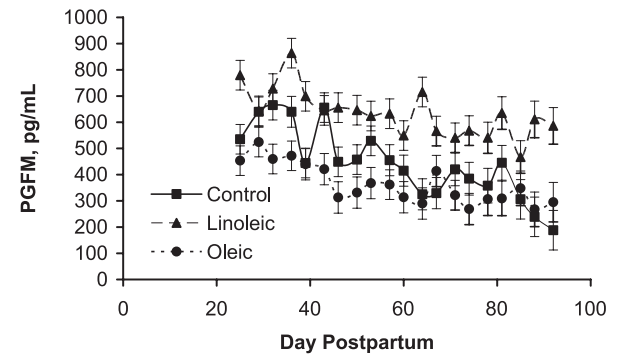

Figure 2. Serum concentrations of $\mathrm{PGF}_{2 \alpha}$ metabolite (PGFM) in primiparous beef cows fed control, linoleate, and oleate supplements from d 3 through d 92 postpartum (least squares means, SE $\leq 73.9$ ). Concentrations of PGFM differed by treatment $(P=0.01)$. Concentrations were influenced by day $(P<0.001)$. Significant treatment by day interactions were not detected $(P=0.13)$.

Trial 2 were influenced by day $(P<0.001)$ and declined from $600 \pm 33 \mathrm{pg} \cdot \mathrm{mL}^{-1}$ at d 25 to $363 \pm 42 \mathrm{pg} \cdot \mathrm{mL}^{-1}$ by $92 \mathrm{~d}$ postpartum in all cows (Fig. 2). As in Trial 1, the concentrations of PGFM were influenced by treatment $(P=0.01)$ and were greater $(P \leq 0.04)$ in cows fed high-linoleate safflower seeds $\left(647 \pm 62 \mathrm{pg} \cdot \mathrm{mL}^{-1}\right)$ than cows fed either high-oleate safflower seeds (371 \pm $\left.68 \mathrm{pg} \cdot \mathrm{mL}^{-1}\right)$ or control supplement $(452 \pm$ $\left.68 \mathrm{pg} \cdot \mathrm{mL}^{-1}\right)$. Treatment by day interactions were not detected $(P=0.13)$.

In Trial 2, relative weight percentages of plasma linoleic $(P<0.001)$, oleic $(P<$ $0.001)$ and arachidonic $(P=0.04)$ acid differed by treatment. Relative plasma concentration of linoleic acid was the greatest $(P<0.001)$ in linoleic-supplemented cows $(29.2 \pm 0.6 \%)$ compared with cows fed oleic $(18.6 \pm 0.6 \%)$ or control (21.2 \pm $0.6 \%$ ) supplements. Cows supplemented with high-oleic safflower seeds had the highest $(P<0.001)$ relative concentrations of plasma oleic acid $(21.5 \pm 0.4 \%)$ compared with linoleic- $(10.5 \pm 0.4 \%)$ or control- $(13.4 \pm 0.4 \%)$ supplemented cows. The relative weight percentage of plasma arachidonic acid was low in all cows; however, differences $(P=0.04)$ were noted among treatments. Relative plasma con- centrations of arachidonic acid were greater $(P=0.01)$ in linoleic-supplemented cows $(1.5 \pm 0.1 \%)$ than in control cows $(1.2 \pm$ $0.1 \%)$. Cows supplemented with higholeic safflower seeds had intermediate relative plasma concentrations (weight \%) of arachidonic acid $(1.4 \pm 0.1 \%)$ that did not differ $(P \geq 0.1)$ from either control- or linoleic-supplemented cows.

\section{DISCUSSION}

Uterine production of $\mathrm{PGF}_{2 \alpha}$ is important during the early postpartum period. Synthesis and secretion of $\mathrm{PGF}_{2 \alpha}$ can decrease the number of days to complete uterine involution and hence, the length of postpartum infertility [20]. Early pregnancy is associated with an attenuation of PG synthesis and secretion that may be partially caused by limited substrate availability [21]. Increases in substrate availability from diets high in PG precursors during early pregnancy could increase production of $\mathrm{PGF}_{2 \alpha}$ and contribute to early luteolysis and embryo mortality [10]. Increased plasma concentrations of PGFM were noted in cows supplemented with high-linoleic safflower seeds in Trial 1. In Trial 2, fatty acid composition of fat supplements differentially influenced plasma concentrations of fatty acids and serum concentrations of PGFM. Although the relative weight percentage of arachidonic acid was low in all cows, cows supplemented with high-linoleate safflower seeds had increased plasma concentrations of arachidonic acid over cows fed the control supplement. Increases in plasma arachidonic acid were also noted in ewes fed a diet high in linoleic acid [7]. Relative plasma concentrations of arachidonic acid were similar in oleic and linoleate supplemented cows possibly due to the amount of linoleic acid present in the high-oleic safflower seed supplement. Although relative weight \% of plasma arachidonic acid was low compared to plasma concentrations of oleic and linoleic acid, these levels may be representative 
of a larger pool in phospholipid stores available for PG synthesis [6].

Plasma concentrations of PGFM were also greater in linoleate-supplemented cows than in cows fed oleate- or control-supplements. Similarly, Brahman cows supplemented with $530 \mathrm{~g} \cdot \mathrm{d}^{-1}$ lipid from rice bran containing approximately equal proportions of oleic and linoleic acid tended to have increased concentrations of serum PGFM [4]. Likewise, beef cows fed $230 \mathrm{~g} \cdot \mathrm{d}^{-1} \mathrm{cal}-$ cium soaps of fatty acids containing $40 \%$ oleic and $9 \%$ linoleic acid also had increased concentrations of PGFM early in the postpartum period [5].

Total flow and postruminal disappearance of unsaturated fatty-acids, especially linoleic acid, were the greatest in cattle fed high-linoleate safflower seeds [9] presumably leading to an increase in milk linoleic acid [22]. Cis-linoleic acid (18:2n-6) can be desaturated and elongated to form dihomo$\gamma$-linolenic acid which serves as an immediate precursor for series one PG or can be desaturated further to arachidonic acid (20:4), an immediate precursor for series two PG [23]. Although not apparent in the present study, linoleic acid may also exert inhibitory effects on PG synthesis by competing with arachidonic acid for binding to cyclooxygenase [23]. Staples et al. [23] suggested the amount of particular fatty acids reaching the target tissues likely influence whether PG synthesis is stimulated or inhibited. Increased concentrations of PGFM in plasma from lipid supplemented cows could be related to increased substrate availability. Scholljegerdes et al. [9] reported an approximate three fold increased availability of intestinal 18:2n-6 for linoleate- compared to control- or oleate-supplemented cows. Moreover, plasma 18:2n-6 greatly increased and 20:4 was the greatest for the linoleate treatment.

Serum concentrations of PGFM decreased with time postpartum in Trial 2 but not in Trial 1. The reasons for this difference are not apparent, but could be related to differences in cow parity [24]. Elevated circulat- ing concentrations of PGFM during the postpartum interval can exert divergent effects on subsequent fertility. High serum concentrations of PGFM early postpartum decreases the time required for uterine involution [20]. Filley et al. [5] reported a negative correlation between the duration of increased $\mathrm{PGF}_{2 \alpha}$ production and the duration of the postpartum anestrous period. Conversely, high serum concentrations of $\mathrm{PGF}_{2 \alpha}$ later in the postpartum interval may reduce subsequent fertility by increasing the incidence of estrous cycles with abbreviated luteal phases resulting in early embryonic mortality $[10,21,25]$.

In conclusion, serum concentrations of PGFM were differentially influenced by dietary oil supplements unique in fatty acid composition. Although potential effects of fat supplementation-induced changes in PGFM on postpartum reproduction have not been proven [26], appropriate supplementation with lipids may provide an alternative method to manipulate $P G$ production during the postpartum interval in order to optimize reproductive performance.

\section{REFERENCES}

[1] Hawkins DE, Niswender KD, Oss GM, Moeller CL, Odde KG, Sawyer HR, Niswender GD. An increase in serum lipids increases luteal lipid content and alters disappearance rate of progesterone in cows. J Anim Sci 1995, 73: 541-545.

[2] Ryan DP, Bao B, Griffin MK, Williams GL Metabolic and luteal sequelae to heightened dietary fat intake in undernourished, anestrous beef cows induced to ovulate. J Anim Sci 1995, 73: 2086-2093.

[3] Thomas MG, Bao B, Williams GL. Dietary fats varying in their fatty acid composition differentially influence follicular growth in cows fed isoenergetic diets. J Anim Sci 1997, 75: 2512-2519.

[4] Lammoglia MA, Willard ST, Hallford DM, Randel RD. Effects of dietary fat on follicular development and circulating concentrations of lipids, insulin, progesterone, estradiol-17 $\beta$, 13,14-dihydro-15-keto-prostaglandin $\mathrm{F}_{2} \alpha$, and growth hormone in estrous cyclic Brahman cows. J Anim Sci 1997, 75: 1591-1600. 
[5] Filley SJ, Turner HA, Stormshak F. Plasma fatty acids, prostaglandin $\mathrm{F}_{2} \alpha$ metabolite, and reproductive response in postpartum heifers fed rumen bypass fat. J Anim Sci 2000, 78: 139-144.

[6] Cheng Z, Robinson RS, Pushpakumara PGA, Mansbridge RJ. Effect of dietary polyunsaturated fatty acids on uterine prostaglandin synthesis in the cow. J Endocrinol 2001, 171: 463-473.

[7] Elmes M, Tew P, Cheng Z, Kirkup SE, Abayasekara DRE, Calder PC, Hanson MA, Wathes DC, Burdge GC. The effect of dietary supplementation with linoleic acid to late gestation ewes on the fatty acid composition of maternal and fetal plasma and tissues and the synthetic capacity of the placenta for 2-series prostaglandins. Biochim Biophys Acta 2004, 1686: 139-147.

[8] Cheng Z, Elmes M, Kirkup SE, Chin EC, Abayasekara DRE, Wathes DC. The effect of a diet supplemented with n-6 polyunsaturated fatty acid linoleic acid on prostaglandin production in early- and late-pregnant ewes. $\mathbf{J}$ Endocrinol 2005, 184: 165-178.

[9] Scholljegerdes EJ, Hess BW, Moss GE, Hixon DL, Rule DC. Influence of supplemental cracked high-linoleate or high-oleate safflower seeds on site and extent of digestion in beef cattle. J Anim Sci 2004, 82: 3577-3588.

[10] Funston, RN. Fat supplementation and reproduction in beef females. J Anim Sci 2004, 82 (E Suppl): E154-E161.

[11] Wagner JJ, Lusby KS, Oltjen JW, Rakestraw J, Wetteman RP, Waters LE. Carcass composition in mature Hereford cows: Estimation and effect on daily metabolizable energy requirement during winter. J Anim Sci 1988, 66: 603-612.

[12] NRC. Nutrient Requirements of Beef Cattle. 7th ed, National Academy Press, Washington DC, 1996.

[13] Alderton BW, Hixon DL, Hess BW, Woodard LF, Hallford DM, Moss GE. Effects of supplemental protein type on productivity of primiparous beef cows. J Anim Sci 2000, 78: 3027-3035.

[14] NRC. United States-Canadian Tables of Feed Composition. 3rd ed, National Academy Press, Washington DC, 1982.

[15] Bottger JD, Hess BW, Alexander BM, Hixon DL, Woodard LF, Funston RN, Hallford DM, Moss GE. Effects of fat supplementation with two types of cracked safflower seeds on postpartum reproduction and production of prim- iparous beef heifers. J Anim Sci 2002, 80: 2023-2030.

[16] Rule DC. Direct transesterification of total fatty acids of adipose tissue, and of freezedried muscle and liver with boron-triflouride in methanol. Meat Sci 1997, 46: 23-32.

[17] Silvia WJ, Niswender GD. Maintenance of the corpus luteum of early pregnancy in the ewe. III. Differences between pregnant and nonpregnant ewes in luteal responsiveness to prostaglandin $F_{2 \alpha}$. J Anim Sci 1984, 59: 746753.

[18] Guilbault LA, Thatcher WW, Drost M, Hopkins SM. Source of F series prostaglandins during the early postpartum period in cattle. Biol Reprod 1984, 31: 879-887.

[19] Steele RGD, Torrie JJ. Principles and Procedures of Statistics: A Biometrical Approach. 2nd ed, New York, McGraw-Hill, 1980.

[20] Madej A, Kindahl H, Woyno W, Edqvist LE, Stupnicki R. Blood levels of 15-keto-13, 14dihydro-prostaglandin $\mathrm{F}_{2 \alpha}$ during the postpartum period in primiparous cows. Theriogenology 1984, 21: 279-287.

[21] Thatcher WW, Binelli M, Burke, Staples CR, Ambrose JD, Coelho S. Antiluteolytic signals between the conceptus and endometrium. Theriogenology 1997, 47: 131-140.

[22] Lake SL, Hess BW, Scholljegerdes EJ, Atkinson RL, Rule DC. Milk and calf adipose tissue fatty acid changes in response to maternal supplementation with high-linoleate or higholeate safflower seeds. J Anim Sci 2004, 82 (Suppl 2): 102.

[23] Staples CR, Burke JM, Thatcher WW. Symposium: Optimizing energy nutrition for reproduction in dairy cows: Influence of supplemental fats on reproductive tissues and performance of lactating cows. J Dairy Sci 1998, 81: 856-871.

[24] Kiracofe GH. Uterine involution: It's role in regulating postpartum intervals. J Anim Sci 1980, 51 (Suppl II): 16-28.

[25] Troxel TR, Kesler DJ. Ability of indomethacin to alter prostaglandin metabolite concentrations and to enhance the function of corpora lutea induced in postpartum suckled beef cows. J Anim Sci 1984, 59: 177-181.

[26] Williams GL, Stanko RL. Dietary fats as reproductive nutraceuticals in beef cattle. Proc Amer Soc Anim Sci 1999. Available from URL: http://www.asas.org/jas/symposia/98-99proc.htm/ [consulted: 16 Nov 2004]. 